- Communication-

\title{
Promotion of Pitting for Type 304 Stainless Steel by Permeated Hydrogen
}

\author{
Hitoshi YASHIRO*, Takashi KodAIRA and Kazuo TANNO
}

Recceived July 18, 1990 ; Accepted September 12,1990

\section{INTRODUCTION}

Evolution of hydrogen is one of the typical cathodic reaction involved in the localized corrosion process of passivated materials. Although the diffusivity of hydrogen within austenitic stainless steel is very low $\left(\sim 10^{-12}\right.$ $\left.\mathrm{cm}^{2} / \mathrm{s} 1\right)$, because of its f.c.c. structure, it has been shown that the uptake of hydrogen is possible even under open circuit condition in deaerated solutions at $368 \mathrm{~K}^{2}$ ). Some amount of hydrogen might diffuse to the surface and affect the passive $f i l m$, as has been suggested for iron and nickel ${ }^{3)}$. In spite of extensive works on hydrogen embrittlement of steels, limited data is available on the change in resistance of passive film against localized corrosion by hydrogen. Hasegawa and Osawa showed that stainless steel that absorbed hydrogen under high temperature and pressure suffered anomalous corrosion, which might be caused by the formation of activated microdefects and unstabilization of passive $\mathrm{films} \mathrm{H}^{4} 5$ ). Armacanqui and $\operatorname{Oriani}{ }^{6)}$ found that passivated nickel became less resistive to pitting by permeated hydrogen using Devanathan's type of cell ${ }^{7}$ ). In the present study, this type of pitting tests have been carried out on type 304 stainless steel.

Department of Applied Chemistry, Faculty of Engineering, Iwate University (Ueda, Morioka, 020 Japan)

Key Words: Pitting, Hydrogen, Permeation, Stainless steel

\section{EXPERIMENTAL}

Commercially available type 304 stainless steel foil ( $50 \mu \mathrm{m}$ thick) was cut into disk, electropolished in $\mathrm{CrO}_{3}-$ $\mathrm{H}_{3} \mathrm{PO}_{4}-\mathrm{H}_{2} \mathrm{O}$, and rinsed. One side of the specimen was sealed leaving about $1 \mathrm{~cm}^{2}$ area, which was submitted to pitting test. Both side of specimen was again electropolished briefly and rinsed ultrasonically. The specimen was assembled into a Devanathan's type of cell which contained $260 \mathrm{~cm}^{3}$ of deaerated 0.1 $\mathrm{M} \mathrm{Na} \mathrm{SO}_{4}$ in a cathodic compartment and $0.1 \mathrm{M} \mathrm{Na}_{2} \mathrm{SO}_{4}+0.5 \mathrm{M} \mathrm{NaCl}$ in an anodic one.

Hydrogen was charged galvanostatically $\left(-1 \mathrm{~mA} / \mathrm{cm}^{2}\right)$ from a cathodic compartment for 24 hours, while open circuit. potential of the other side of the specimen was monitored. Then, an anodic polarization curve was measured at 100 $\mathrm{mV} / \mathrm{min}$ in the anodic compartment. Impedance measurement was also carried out for anodic side.

In the separate experiments, the anodic side of a specimen was polarized to the passive region ( $250 \mathrm{mV}$ vs. SHE at $343 \mathrm{~K}$ ) in chloride free solution, while hydrogen was charged from cathodic side for 24 hours. Then, $\mathrm{NaCl}$ was added to anolyte so that the concentration of chloride became $0.5 \mathrm{M}$ and induction period for pit initiation was measured.

All experiments were carried out at $343 \mathrm{~K}$. Potentials measured against $\mathrm{Ag} / \mathrm{AgCl} / \mathrm{KCl}(0.5 \mathrm{M})$ reference electrode were converted into SHE scale at $343 \mathrm{~K}$. 


\section{RESULTS AND DISCUSSION}

Fig. 1 shows variation of corrosion potential of anodic side with or without hydrogen permeation. With progress of permeation of hydrogen, the corrosion potential became less noble and reached around $-400 \mathrm{mV}$, which corresponded to redox potential for hydrogen at the $\mathrm{pH}$ of this solution $(5.5-6.0)$. The impedance measurement showed that the apparent film resistance reduced significantly ( from $2 \times 10^{6}$ to $4 \times 10^{3} \Omega \mathrm{cm}^{2}$ ) while the apparent capacitance increased ( from 150 to $250 \mu \mathrm{F} \mathrm{cm}{ }^{-2}$ ), suggesting that the film suffered changes in thickness and composition.

Fig. 2 shows the polarization curves of anodic side after 24 hours charging of hydrogen. In chloride free solutions, the difference between 1 ine 1 and 2 is attributed to oxidation of permeated hydrogen and accelerated transpassive dissolution ${ }^{8)}$. Pitting potentials observed in chloride containing solutions had significant difference between charged and uncharged specimen. Appar-

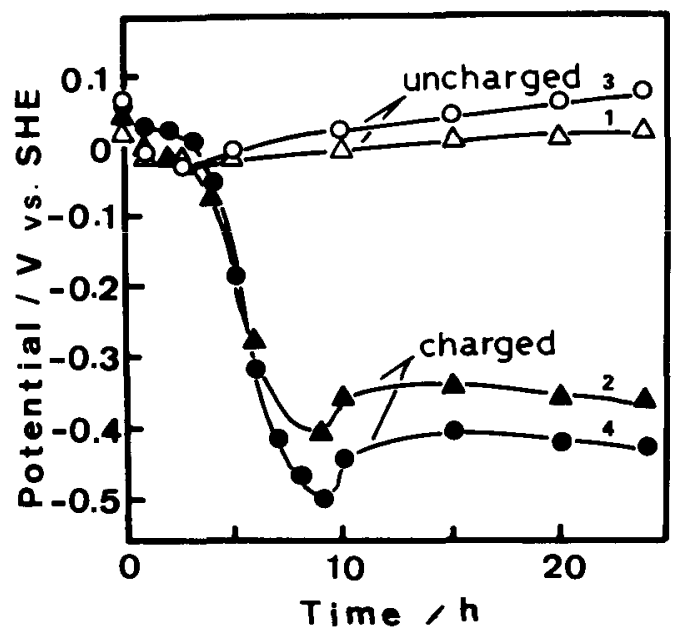

Fig. 1 Variation of corrosion potential of type 304 stainless steel with permeation of hydrogen at $343 \mathrm{~K}$

Solution: $0.1 \mathrm{M} \mathrm{Na}_{2} \mathrm{SO}_{4}$ for 1 and 2

$0.1 \mathrm{M} \mathrm{Na}_{2} \mathrm{SO}_{4}+0.5 \mathrm{M} \mathrm{NaCl}$ for 3 and 4 ently, hydrogen seems to enhance the pitting susceptibility of stainless steel.

Since pitting is usually characterized by pitting potential and induction period, the effect of hydrogen on the induction period was examined. Anodic side of specimen was polarized at $250 \mathrm{mV}$ for 24 hours during charging of hydrogen from cathodic side. The induction period for pit initiation after addition of $\mathrm{NaCl}$ typically distributed 10 through 20 minutes. Since pitting period is strongly depends on passivation time, the induction period for an uncharged specimen was measured as a function of it at $250 \mathrm{mV}$. When $\mathrm{NaCl}$ was added to the solution after passivation at $250 \mathrm{mV}$ for 24 hours, the induction period ranged from 78 to 296 minutes, while it did not exceed 30 minutes when $\mathrm{NaCl}$ was added just after the specimen was polarized at. $250 \mathrm{~m} v$. The induction period for pitting has been recognized to become

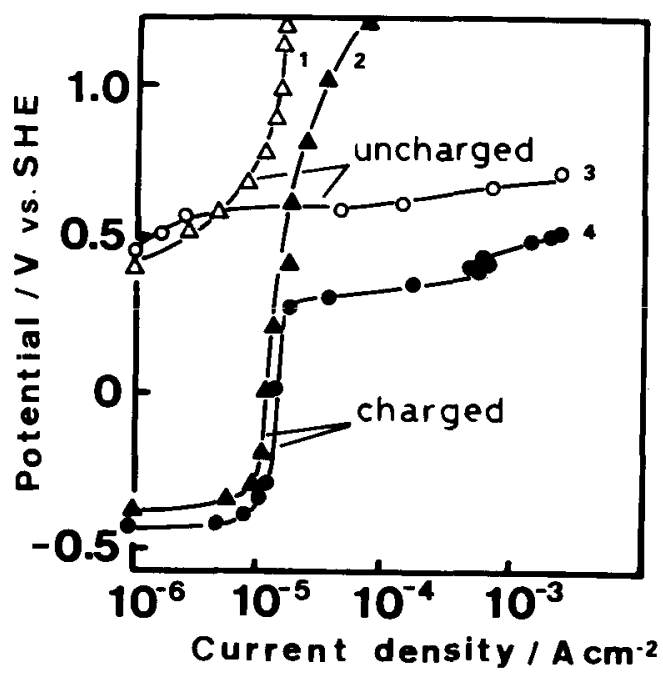

Fig. 2 Effect of permeated hydrogen on the anodic polarization behavior of type 304 stainless steel at $343 \mathrm{~K}$

Solution: $0.1 \mathrm{M} \mathrm{Na}_{2} \mathrm{SO}_{4}$ for 1 and 2 $0.1 \mathrm{M} \mathrm{Na}_{2} \mathrm{SO}_{4}+0.5 \mathrm{M} \mathrm{NaCl}$ for 3 and 4

Scan rate: $100 \mathrm{mV} / \mathrm{min}$ 
longer with ageing of passive $f i l \mathrm{~m}^{9}$ ). The permeated hydrogen seemed to reduce this ageing effect.

The induction period for pitting is known to depend on both film thickness and composition ${ }^{9}$ ). It may be possible that the permeated hydrogen reduces passive film, which results in thinning of it. The permeated hydrogen may also change the composition of films as has been pointed out by Pyun and Oriani ${ }^{3)}$. Furthermore, the oxidation of permeated hydrogen at the $\mathrm{film} / \mathrm{solution}$ interface might enhance the local concentration of hydrogen ion. Transition of austenitic phase to martensitic one at anodic side would not be significant, since it is limited to charging surface layer of 8 $\mu$ depth even under severe charging condition ${ }^{10)}$. Although the precise role of hydrogen is not clear in the present stage, elucidation of it would lead to better understanding of general pitting mechanism and characterization of passive films.

\section{REFERENCES}

1) T. Zakroczymsky, Z. SzklarskaSmialowska and M. Smialowski, Corrosion, 39,207 (1983).

2) N. Ohnaka and Y. Furutani, Corrosion, 46, 129 (1990).

3) Su-Il Pyun and R. A. Oriani, Corros. Sci., 29,485 (1989).

4) Motoaki Osawa and Masayoshi Hasegawa, Trans. ISIJ, 21464 (1981).

5) Masayoshi Hasegawa and Motoaki Osawa, Corrosion, 36, 67 (1880).

6) M. E. Armacanqui and R. A. Oriani, Corrosion, 44, 696 (1988).

7) M. A. V. Devanathan, Z, Stachurski and W. Beck, J. Elecrochem. Soc., 110, 886 (1963).

8) L. Quao, W. Chu, C. Hsiao and H. Huang, Proc. of 10 th ICMC, India, p. 2389 (1987).

9) Z. Szklarska-Smialowska, Pitting Corrosion of Metals, NACE, (1986).

10) P. Rozenak and D. Eliezer, Acta metall., 35, 2329 (1987). 